Review Article

\title{
Microbial xylanases and their biomedical applications: a review
}

\author{
Girish K. Goswami ${ }^{1}$, Rakesh R. Pathak ${ }^{2 *}$
}

${ }^{1}$ Amity Institute of Biotechnology, Amity University, Jaipur,

Rajasthan, India

${ }^{2}$ Department of Pharmacology,

C.U. Shah Medical College,

Surendranagar 363001, India

Received: 19 March 2013

Accepted: 14 April 2013

*Correspondence to:

Dr. Rakesh R. Pathak,

Email: rr_pathak@yahoo.com

(C) 2013 Goswami GK et al. This is an open-access article distributed under the terms of the Creative Commons Attribution License, which permits unrestricted use, distribution, and reproduction in any medium, provided the original work is properly cited.

\begin{abstract}
Xylanases have a great potential, mainly known for industrial applications. They can hydrolyze the xylose (Hemicellulose of plant cell wall) and can be used for bio-bleaching the kraft pulp. As it reduces the requirement of harsh chemicals in the process, it can be used further to a number of bio-products with a great aggregate value. Microbial-origin xylanases can also be used in improving the nutritional quality of animal feed (e.g. food additives to poultry, piggery or fishery) and indirectly affect the humans. Additionally they can be used directly in human food in bakery, clarification of juices and in xenobiotics like tobacco processing. The great value of xylanase as a bio-bleaching agent has now a new dimension of fiber digesting agent having relevance to food, drugs and cosmetics act. This review presents some important applications of Xylanases extended up to biomedical sciences.
\end{abstract}

Keywords: Xylan, Xylanase, Industry, Medical, Veterinary, Agricultural

\section{INTRODUCTION}

Enzymes are the central attraction point in metabolic and biochemical processes. In yonder days, people were also using the enzymes in various processes of distillery and bakery. As a result of that, they are widely studied not only by the biological community, but also by the process designers, chemical engineers, production experts and other scientific peoples. Though the concept of thermostable xylanase came in early 80's (Yoshioka et $\mathrm{al}^{99}$, 1981; Uchino et al, $1981^{86}$ ), the application of xylanase in paper and pulp industry was first reported by Viikari et al in $1986 .^{92}$ In their study, they have claimed that endoxylanases decrease chemicals needed for bleaching kraft pulp. Many researchers (Paice et al $1988^{68}$, Clark et al $1990^{23}$ ) have confirmed and extended this observation.

Kraft pulp is what we get after we place a chip of wood in a pressurized vessel in the presence of hot caustic soda and sodium sulfide. The cooking process attacks and eventually dissolves the phenolic material called lignin that glues the fibers to each other in the wood. The word "kraft" means "strong" in the language of its origin.
German manufacturers of pulp discovered that addition of the sulfur to a "soda cook" improved the selectivity of the process - dissolving the lignin with less damage to the cellulose (Mini-Encyclopedia of Papermaking). ${ }^{58}$ Xylanase treatment decreases $\mathrm{ClO}_{2}$ demand, decreasing net bleaching costs by $3.4 \%$ and has several effects on the strength of the unrefined pulp without negatively affecting customer requirements (Tolan \& Collins, 2004). ${ }^{83}$

The scope of revised version of Food and Drugs acts, 1940 has been recently grown far more extensive cosmeceuticals and nutraceuticals now also fall under its purview. Food additives like preservatives, emulsifiers, coloring agents, flavoring agents, jellying agents, sweeteners etc are also under this observation. Xylanase is used in fodder industry for poultry (Momtazan et $\mathrm{al}^{59}$, 2011, Barekatain, 2012 ), piggery (Malagutti et al, $2010^{57}$ ) and fishery (Huichang C, 2006 ${ }^{37}$; Yildirim $2010^{98}$ ) - thus indirectly effecting humans (Verhoeven et al, 2005). ${ }^{88}$ Application of xylanase in juice, alcohol, tobacco and bakery industry has direct impact on human health. Thus the effect of xylanase is also medically and pharmacologically much more relevant heretofore. 


\section{BIOTECHNICAL BACKGROUND OF XYLANS}

Plant cell walls have three major polymeric constituents: cellulose (Insoluble fibers of $\beta$-1,4-glucan), hemicellulose (non-cellulosic polysaccharides including glucans, mannans and xylans) and legnin (A complex poly phenolic structure). Xylan is the major hemicellulaose in wood from angiosperms but is less abundant in wood from gymnosperms like ferns (Akhtar et al, 1997). ${ }^{3}$

Lignocelluloses are mainly secondary plant cell-wall materials which consist of lignin, cellulose and hemicelluloses. D-xylan is the major hemi-cellulose found in woods and accounts for $20-35 \%$ of the total dry weight of hardwood and perennial plants. The basic structure of xylan is a $\beta$-D- $(1,4)$-linked xylopyranosyl residue with a few branch points. The major backbone carries relatively short side chains of variable lengths. Due to the abundance and the structural heterogeneity of xylans, xylan-degrading enzymes are diverse (Lee et al., 2003). ${ }^{51}$

\section{BIOTECHNICAL XYLANASES}

\section{BACKGROUND}

OF

Typical xylan-degrading enzymes are endo- $\beta$-xylanases (EC 3. 2. 1. 8) which attack the main chain of xylans, and $\beta$-xylosidases (EC 3. 2. 1. 37) which hydrolyze xylooligosaccharides into D-xylose. These two enzymes, also required for complete hydrolysis of native cellulose and biomass conversion, are produced by many bacteria and fungi. Potential applications of xylanase in biotechnology include bio-pulping of wood, pulp bleaching, treating animal feed to increase digestibility, processing food to increase clarification, and converting lignocellulosic substances into feed stocks and fuels (Kim et al., 2000). ${ }^{46}$

Filamentous fungi are attracting greater attention than bacteria as potential sources of plant cell wall hydrolyzing enzymes such as xylanases because they secrete high levels of the enzymes into the culture medium. In search for microorganisms capable of efficiently degrading lignocelluloses, some cellulolytic microfungi including a wild strain of Aspergillus niger (ANL301) were isolated from decomposing wood-wastes in Lagos, Nigeria (Nwodo-Chinedu et al., 2005). ${ }^{68}$ This microfungus grows effectively in mineral salt medium supplemented with sawdust or sugarcane as sole carbon sources (Nwodo-Chinedu et al., 2007). ${ }^{64}$

Xylanase can be used as a bio-bleach for pre-bleaching the Kraft pulp to reduce the use of harsh chemicals in paper and pulp Industry. Xylanses are not only used in pulp and paper industry or degumming of plant fiber sciences like flex, hemp, jute and ramie (Karaduman et $\mathrm{al}, 2012)^{43}$ but also in many food supplement, veterinary, and agricultural processing.
About 300 different chlorinated organic compounds have been identified in bleaching pulp mill effluents (Verma et al, 2012). ${ }^{90}$ About 200 of these have chlorinated resin acids, chlorinated phenolics and dioxin. These compounds have been classified as acidic, phenolic and neutral and are partly responsible for oxygen demand (OD), effluent color, toxicity mutagenicity and carcinogenicity - untreated pulp and paper mill effluents can be extremely toxic to aquatic life too. This chemical pollution can be minimized by extensive use of xylanases (Zhang et $\mathrm{al}^{100}, 2008$; Yadav et $\mathrm{al}^{97}, 2012$ ).

\section{MICROBIAL SOURCES OF XYLANASES}

The multifunctional xylanolytic enzyme system is wide spread among Fungi (Belancic et al 1995) ${ }^{12}$, Actinomycetes (Suneetha $\mathrm{V}$ et al, 2011) ${ }^{81}$ and bacteria (Dey et al 1992). ${ }^{25}$ Table 1 summarizes the biochemical properties of some acidic, alkaline, and thermostable xylanases reported in literature.

\section{RECENT ARRIVALS}

For obtaining industrially important xylanases alkaliphilic organism and thermophilic organism have been preferred. Alkaline xylanases are important due to their applications in pulp and kraft bleaching. Horikoshi and Atsukawa reported alkaliphilic bacteria for xylanase production for the first time in 1973.

The enzymes from Bacillus sp. TAR-1, C-125 (Nakamura et al 1994) $^{63}$ and alkaliphilic Bacillus sp (NCL-86-6-10) (Balakrishna et al., 1992) ${ }^{6}$ were optimally active at $\mathrm{pH}$ 9-10. The Xylanase from Cephalosporium was the only one reported from an alkaliphilic fungus having activity at broad $\mathrm{pH}$ range of 6.5-9 (Bansod et al 1993). ${ }^{7}$ Alkali/thermo-stable xylanase gene from Bacillus sp. StrainNG-27 in tobacco plants active up to $42^{\circ} \mathrm{C}$ have been shown by the turn of century (Leelavathi et al, 2003). ${ }^{52}$

Soon halo-alkali-thermo-tolerant varieties were known retaining more than $80 \%$ of activity at $30 \% \mathrm{NaCl}$ and $76 \%$ of activity at $\mathrm{pH} 10.5$ (Giridhar et al, 2010). ${ }^{30} \mathrm{In}$ some strains, optimal xylanase activity was observed at $\mathrm{pH} 6.4$ and temperature $55^{\circ} \mathrm{C}$ and xylanase is active up to $\mathrm{pH} 9(40.33 \mathrm{IU} / \mathrm{ml})$ and temperature $85^{\circ} \mathrm{C}(48.81 \mathrm{IU} / \mathrm{ml})$ (Agnihotri et al, 2010) ${ }^{1}$ and A 27-fold higher production was achieved by cloning and expression (Verma et al, 2011). ${ }^{89}$

Recently thermostable xylanase retaining activity at $100^{\circ}$ $\mathrm{C}$ for 20 minutes have been found (Hokanson et al, 2011). ${ }^{35}$ Bacillus haloduras is a wild (non-genetically manipulated) organism yielding thermo-alkali stable xylanase that acts in submerged fermentation at $\mathrm{pH} 10.0$ (Kumar et al, 2012). ${ }^{48}$ To the contrary, thermo-acid stable variants act at $\mathrm{pH} 2.0$ and temperature $80^{\circ} \mathrm{C}$ (Apel et al, 2008). ${ }^{4}$ 
Table 1: Characteristics of xylanases from different microorganisms (kDa kilodaltons).

\begin{tabular}{|c|c|c|c|c|c|}
\hline \multirow[b]{2}{*}{ Microorganism } & \multirow{2}{*}{$\begin{array}{l}\text { pl = } \\
\text { Isoelectric } \\
\text { Point }\end{array}$} & \multirow{2}{*}{$\begin{array}{l}\text { Molecular } \\
\text { weight (kDa) }\end{array}$} & \multicolumn{2}{|l|}{ Optimum } & \multirow[b]{2}{*}{ References } \\
\hline & & & pH & $\begin{array}{l}\text { Temperature } \\
\left({ }^{0} \mathrm{C}\right)\end{array}$ & \\
\hline \multicolumn{6}{|l|}{ Bacteria } \\
\hline Acidobacterium capsulatum & 7.3 & 41 & 5 & 65 & Inagaki et al. $1998^{39}$ \\
\hline Bacillus circulans WL-12 & 9.1 & 15 & $5.5-7$ & - & Joshi et al. $2008^{41}$ \\
\hline Bacillus stearothermophilus T-6 & 7,9 & 43 & 6.5 & 55 & Khasin et al. $1993^{45}$ \\
\hline Bacillus polymyxa CECT 153 & 4.7 & 61 & 6.5 & 50 & Morales et al. $1995^{60}$ \\
\hline Bacillus sp. strain K-1 & - & 23 & 5.5 & 60 & $\begin{array}{l}\text { Ratannaka- nokchai et } \\
\text { al. } 1999^{72}\end{array}$ \\
\hline Bacillus sp. NG-27 & - & - & $7,8.4$ & 70 & Gupta et al. $1992^{31}$ \\
\hline Cellulomonas fimi & $4.5-8.5$ & $14-150$ & $5-6.5$ & $40-45$ & Khanna $1993^{44}$ \\
\hline Cellulomonas sp. N.C.I.M. 2353 & 8 & $22,33,53$ & 6.5 & 55 & $\begin{array}{l}\text { Chaudhary and } \\
\text { Deobagkar } 1997^{17}\end{array}$ \\
\hline Staphylococcus sp. SG-13 & - & 60 & $7.5,9.2$ & 50 & Gupta et al. $2000^{32}$ \\
\hline $\begin{array}{l}\text { Thermoanaerobacterium sp. } \\
\text { JW/SL-YS } 485\end{array}$ & 4.37 & $24-180$ & 6.2 & 80 & Shao et al. $1995^{75}$ \\
\hline Thermotoga maritima MSB8 & 5.6 & 40,120 & $5.4,6.2$ & $92-105$ & $\begin{array}{l}\text { Winterhalter and } \\
\text { Liebel } 1995^{94}\end{array}$ \\
\hline \multicolumn{6}{|l|}{ Fungi } \\
\hline Aspergillus niger ANL-301 & 9 & $13.5-14.0$ & 5.5 & 45 & Okafor et al $2010^{66}$ \\
\hline Aspergillus kawachii IFO 4308 & $3.5-6.7$ & $26-35$ & $2-5.5$ & $50-60$ & Ito et al. $1992^{40}$ \\
\hline Aspergillus sojae & $3.5,3.75$ & $32.7,35.5$ & $5,5.5$ & 60,50 & Kimura et al. $1995^{47}$ \\
\hline Aspergillus sydowii MG 49 & - & 30 & 5.5 & 60 & $\begin{array}{l}\text { Ghosh and Nanda } \\
1994^{29}\end{array}$ \\
\hline Cephalosporium sp. & - & 30,70 & 8 & 40 & Bansod et al. $1993^{7}$ \\
\hline Fusarium oxysporum & - & $20.8,23.5$ & 6 & 60,55 & $\begin{array}{l}\text { Christako-polous et } \\
\text { al.1996 }\end{array}$ \\
\hline Geotrichum candidum & 3.4 & $60-67$ & 4 & 50 & $\begin{array}{l}\text { Radionova et al. } \\
2000^{72}\end{array}$ \\
\hline Penicillium purpurogenum & $8.6,5.9$ & 33,23 & $7,3.5$ & 60,50 & Belancic et al. $1995^{12}$ \\
\hline $\begin{array}{l}\text { Thermomyces lanuginosus DSM } \\
5826\end{array}$ & 4.1 & 25.5 & 7 & $60-70$ & Cesar and Mrsa $1996^{16}$ \\
\hline Trichoderma harzianum & - & 20 & 5 & 50 & Ahmed et al $2011^{2}$ \\
\hline Trichoderma reesei & $9,5.5$ & 20,19 & $5-5.5,4-4.5$ & 45,40 & Tenkanen et al. $1992^{82}$ \\
\hline Yeast & & - & - & & \\
\hline $\begin{array}{l}\text { Aureobasidium pullulans Y- } \\
\text { 2311-1 }\end{array}$ & 9.4 & 25 & 4.4 & 54 & Li et al. $1993^{53}$ \\
\hline Cryptococcus albidus & - & 48 & 5 & 25 & Morosoli et al. $1986^{62}$ \\
\hline Trichosporon cutaneum SL409 & - & - & 6.5 & 50 & Liu et al. $1998^{55}$ \\
\hline
\end{tabular}




\begin{tabular}{|llllll|}
\hline Streptomyces sp B-12-2 & $4.8-8.3$ & $23.8,40.5$ & $6-7$ & $55-60$ & Elegir et al. 1995 $^{26}$ \\
\hline $\begin{array}{l}\text { Streptomyces thermoviolaceus } \\
\text { OPC-520 }\end{array}$ & $4.2,8$ & 33,54 & 7 & $60-70$ & Tsujibo et al. 1992 ${ }^{85}$ \\
\hline $\begin{array}{l}\text { Streptomyces viridisporus T7A } \\
\text { Streptomyces } s p \text {. }\end{array}$ & $10.2-10.5$ & 59 & $7-8$ & $65-70$ & $\begin{array}{l}\text { Magnuson and } \\
\text { Crawford } 1997^{56}\end{array}$ \\
\hline QG-11-3 & - & - & 8.6 & 60 & Beg et al. 2000 \\
\hline Thermomonospora curvata & $4.2-8.4$ & $15-36$ & $6.8-7.8$ & 75 & $\begin{array}{l}\text { Stutzenberger and } \\
\text { Bodine } 2008^{80}\end{array}$ \\
\hline
\end{tabular}

A cellulase-free, thermo-alkali-stable, salt- and solventtolerant xylanase (Bhxyl) showed $60 \%$ activity even at $\mathrm{pH}$ 12. It is highly tolerant (> 85\%) to organic solvents $(50 \%$ $\mathrm{v} / \mathrm{v})$ and surfactants (1\%) (Woldesenbet et al, 2012). ${ }^{95}$

\section{INDUSTRIAL PRODUCTION OF XYLANASE}

Xylanase production depends on Media composition and inducing substrate. Filamentous fungi produce more Xylanase than the Yeast and bacteria but in the very beginning, fungal Xylanases was found generally associated with cellulase (Velkova et al, 2007). ${ }^{87}$

Trichoderma \& Aspergillus species produces xylanase by using pure Xylan as substrate for enzyme production. These strains produces both cellulase and xylanase on using cellulose as a substrate, which may be due to the presence of traces of hemi cellulose in the cellulosic substrates (Biely 1993) ${ }^{14}$, The process that controls the extra cellular enzyme-production according to the carbon sources of medium are influenced by the availability of precursors for protein synthesis.

Lower nitrogen/carbon ratio in the medium may be one of the strategies for cellulase free xylanase production (Biely 1991). ${ }^{13}$ Cellulosic substrates in the medium were also found to be essential for the maximum xylanase production (Stutzenberger and Bodine 2008). ${ }^{80}$ Agro waste substrates like corncob, rice straw, wheat straw, wheat bran, corn stalk and bagasse can be used as a substrate for xylanase production by certain microorganisms like Aspergillus awanian and Penicilluim purpurogenum (Ravanal et al, 2012). ${ }^{74}$

Cellulase free Xylanase producer has been reported in Bacillus sp and fungi (Dey et al., 1992). ${ }^{25}$ Xylanase activity is found to be higher in fungal system (with maximum activity of $3350 \mathrm{IU} / \mathrm{ml} \mathrm{In}$ Trichoderma reesei) than Bacterial systems (Haapala et al 1994) ${ }^{33}$ Maximum activity $(22,700 \mathrm{IU} / \mathrm{g})$ in solid-state formation was achieved from the fungus Schizophyllum commune (Haltrich et al 1995). ${ }^{34}$

Fungi generally require acidic $\mathrm{pH}$ but Actinomycetes and bacteria require neutral or alkaline $\mathrm{pH}$ optima for xylanase production. Trichoderma reesei (Tenkanen et al
1992) ${ }^{82}$ Thermomyces (Bajpai 1999) ${ }^{5}$, Aureobasidium pullulans (Christov et al., 1999) ${ }^{22}$. B. subtilis (Wilson et al, 1999) are some of the strain for xylanase production at commercial level. ${ }^{93}$

Due to their Industrial potential, microbial xylanolytic enzymes have drawn a great attention in the last decade. The most promising and wide spread use of Xylanase is in the prebleaching of kraft pulps (Bajpai 1999). ${ }^{5}$ On the laboratory scale, Xylanases come from Streptomyces roseiscleraticus (Patel et al., 1993) ${ }^{71}$ and Actinomycetes (Davis et al., 1992) ${ }^{24}$. T. harzianum (Ahmed et al, 2011) and Humeeala Sp. (Silva et al., 1994) ${ }^{77}$ have been used for enzymatic pulp treatment to check their bleach boosting abilities.

Xylanase enzyme from Thermatoga maritima was compared with commercial pulpzyme $\mathrm{Hc}$ and was found to be efficient in releasing lignin from kraft pulp (Chen $e t$ al., 1997 $)^{20}$. The cloned xylanase expressed in Bacillus cereus (Tremblay and Archibold 1993) ${ }^{84}$ and in E. coli (Chen et al, 2012) ${ }^{20}$ have also been reported to improve the delignification of unbleached kraft pulps. Xylanases produced by many alkali tolerant strains having $\mathrm{pH}$ optima around 9 have been used for bio bleaching.

Thermostable Xylanase produced by Dictyoglomus $s p$ has been evaluated for its suitability in pulp bleaching (Ratto $e t$ al., 1994). ${ }^{73}$ Xylanase from Bacillus stereothermophilus T6 at $65^{\circ} \mathrm{C}$ and $\mathrm{pH} 9$ bleached the pulp effectively and has been industrially used in successful Metl trial (Lapidot 1996). ${ }^{49}$ Novo Nordisk A/S under the brand name of "Pulpzyme HA' marketed first commercial xylanase produced by $T$. ressei. Later on, new enzymes from bacterial source were also sold under the same brand name.

Sandoz chemicals has also marketed it as 'Cartazyme HS". Ecopulp (from Alko-ICI), cartazyme NS-10 (from clariant) and pulpzyme (from Novo Nordisk) were tested with Eucalyptus kraft pulps and the significant decrease in $\mathrm{ClO}_{2} \& \mathrm{H}_{2} \mathrm{O}_{2}$ consumption was observed (Vicuna et al., 1997). ${ }^{91}$ Some important commercial xylanase and their suppliers are given in Table 2. In February 2007 an application has been submitted by DANISCO Animal Nutrition (UK) for approval of DANISCO xylanase G and DANISCO xylanase $\mathrm{L}$ as a feed additive. 
Table 2: Commercial Xylanase and their suppliers.

\begin{tabular}{|lll|}
\hline S. No. & Enzyme & Commercial Supplier \\
\hline 1. & Ecopulp & Alko Rajamaki, Finland \\
\hline 2. & Cartazyme & Sandoz,Charlotte,N.C. and Basel,Switzerland \\
\hline 3. & $\begin{array}{l}\text { Cartazyme HS 10, Cartazyme SR 10 Cartazyme } \\
\text { PS10, Cartazyme 9407, Cartazyme NS10 }\end{array}$ & Clarient, UK \\
\hline 4. & $\begin{array}{l}\text { Irgazyme 40-4X/Albazyme 40-4X, Irgazyme- } \\
\text { 10A,Albazyme-10A }\end{array}$ & Genercor, Finland; Ciba Giegy, Switzerland \\
\hline 5. & VAI Xylanase & Voest Alpine, Austria \\
\hline 6. & Pulpzyme HA, HB and HC & Novo Nordisk, Denmark \\
\hline 7. & $\begin{array}{l}\text { Ecopulp X-100,200, 200/4,TX-100,TX200 and } \\
\text { Ecopulp XM }\end{array}$ & Rohn Enzyme 0Y;Primalco, Finland \\
\hline 8. & Xylanase & Meito Sankyo, Nogaya Japan \\
\hline 9. & Ecozyme & Thomas Swan, UK \\
\hline 10. & GS-35, HS70 & Iogen, Canada \\
\hline 11. & Sanzyme X,PX and Alpelase F & Sankyo, Japan \\
\hline 12. & Enzeko xylanase & Enzyme Development, USA \\
\hline
\end{tabular}

\section{SCOPE OF XYLANASE USE IN INDUSTRY}

1. Agro waste treatment: Hemicelluloses (Xylan) rich agro waste can be treated by Xylanase to convert xylan into xylose by enzymatic hydrolysis. Development of an efficient enzymatic hydrolysis process offers new prospects for treating hemicellulosic wastes and application in biogas production unit (Stalin et al, 2012). ${ }^{79}$ As a pleasant surprise, xylanase can itself be generated from agro waste. The production of a low molecular weight xylanase by Aspergillus carneus M34 was investigated in solid-state fermentation using agricultural waste as the substrate (Fang et al, 2010). ${ }^{27}$

2. Degumming: Xylanase system with Pectinolytic enzyme system can be used for the degumming of bast fibers (Fu et al, 2008) ${ }^{28}$ such as flax, hamp, jute and ramie. Xylanase pectinase combination can also be used in the debarking process, the first step in wood processing (Wong \& Saddler 1997). ${ }^{96}$ Pectinases are believed to play a major role in removal of binding materials from plant tissues, but xylanase may also be involved in this process.

3. Fermentation: A fungal B-glucanase from A. niger is used in the fermentation of beer to avoid the difficulties encountered in filtration and haze by B- glucans. Xylanase is also one of the components of 'Ultraflo L' produced by Humicola insolens, a heat stable multi active B- glucanase can be used in the mashing process in beer brewing to secure an efficient break down of B- glucans
(Ostergaard et al, 2010 67 , Simpson et al, 2012 ${ }^{78}$ ). The activity of xylanase in composition with $\alpha$-amylase and glucoamylase has been selected to achieve a higher ethanol yield in the distillate, by decreasing the concentrations of methanol, propanol, isobutanol and isoamyl \& amyl alcohols' concentration (Juodeikiene et al, 2011). ${ }^{42}$

4. Biofuels: Xylanase in synergism with mannanase xylosidase, glucanase, ligninase, glucosidase etc, may be used for the generation of biological fuels, such as ethanol and xylital from lignocelluloic biomass (Stalin et al, 2012). ${ }^{79}$ The bio process of ethanol fuel production requires de-lignification of lignocelluloses to liberate cellulose and Hemicellulose from their complex with lignin, followed by cellulose and hemicelluloses depolymerization, to produce free sugars and finally fermentation of mixed pentose \& hexose to produce ethanol (Lee 1987). ${ }^{50}$

\section{USE OF XYLANASES IN BIOSCIENCES}

Apart from the major application of Xylanases in pulp bleaching (Beg et al 2001) ${ }^{11}$, some other applications of Xylanse are as follow.

1. Bread Quality Improvement: Xylanase improves the bread quality with an increase in specific bread volume. This can be further enhanced by combining amylase with Xylanse (Chen et al., 2010). ${ }^{19}$ 
2. Non-bakery Food Industry: Xylanase with cellulase and pectinase are used for clarifying must and juices (Pal et al, $2011^{69}$; Sharma et al, 2012 ${ }^{76}$ ), for liquefying fruits and vegetables (Biely 1991). ${ }^{13}$ Xylanase is used in combination with peelinase and cellulase for clarification of fruit juices (Biely 1991). ${ }^{13} \alpha$-L- arabinofuranosidase and $\beta$ - D- gluco pyranosidase have been additionally employed for aromatizing musts wines and fruit juices (Li et al, 2011). ${ }^{54}$

3. Diet of pets: Xylanase incorporation to a rye-based diet of broiler chickens results in reduced intestinal viscosity, this improves both the weight gain of chicks and their feed conversion efficiency and given with proteases increases food conversion ratio (FCR). The same way, xylanase has applications in poultry (Momtazan et al, $2011^{59}$, Barekatain, 2012 ), piggery (Malagutti et al, $2010^{57}$ ) and fishery (Huichang C, 2006 ${ }^{37}$; Yildirim $\left.2010^{98}\right)$.

4. Plant product processing: Xylanase can induce glycosylation and fatty acylation of phytosterols in plant cells Treatment of tobacco cell suspension (Nicotiana tobaccum CV. KY 14) with a purified endo-xylanase from T.viride caused a 13 - fold increase in the levels of acylated sterol glycosides and elicited the syntheses of phytoalexins (Moreau et al., 1994). ${ }^{61}$ Transgenic expression of endoglucanase and xylanase genes increases tobacco digestibility and biomass conversion (Pappan et al, 2009). ${ }^{70}$ Few xylanases can be used for improving cell wall maceration for the production of plant protoplast. Truncated bacterial xylanase gene from Clostridium thermocellum has been demonstrated in rhizosecretion in transgenic tobacco plants (Borisjuk et al., 1999). ${ }^{15}$

5. Seed germination: Xylanases from the germinating plant seed convert reserve food to the assimilable end product. It is proposed that xylanase play a role in cell elongation; fruit softening (Bapat et al, 2010). ${ }^{8}$

6. Miscellaneous: Xylanases are also used in wheat flour for improving dough handling and quality of baked products (Chen et al 2010) ${ }^{19}$, for the extraction of coffee, plant oils, and starch (Wong \& Saddller 1992) ${ }^{96}$, in the improvement of nutritional properties of agricultural silage and grain feed (Iji et al, 2011). ${ }^{38}$

\section{CONCLUSION}

Seeing multiple sources of origin of xylanases and accordingly varying structural, chemical and physical properties vis a vis multiple uses of any given xylanase leading to varying accumulation into biomass directly or indirectly, finally leads to a much complex effect on human population. Human exposure to xylanase as a savior from chemical pollutants might have a sinister side of unexpected and untoward effect too which needs to be evaluated thoroughly.

\section{REFERENCES}

1. Agnihotri S, Dutt D, Tyagi CH, Kumar A, Upadhyaya JS. Production and biochemical characterization of a novel cellulase-poor alkalithermo-tolerant xylanase from Coprinellus disseminatus SW-1 NTCC 1165.World J Microbiol Biotechnol 2010;26:1349-59.

2. Ahmed S, Jabeen A, Jamil A. Xylanase from Trichoderma harzianum: Enzyme characterization and gene isolation. J Chemical Society Pakistan 2011;29:176.

3. Akhtar M, Blanchette R, Kent Kirk T. Fungal delignification and biomechanical pulping of wood. Biotechnology in the Pulp and Paper Industry, 1997:159-95.

4. Apel WA, Thompson VS, Thompson DN, Schaller KD. An overview of studies to characterize a thermo-acid stable xylanase and a thermo-alkali stable catalase from Yellowstone National Park bacteria. In The Annual Meeting and Exhibition 2008.

5. Bajpai P, Bajpai PK, Kondo R. Decolorization and Detoxification of Bleached Kraft Effluents. In Biotechnology for Environmental Protection in the Pulp and Paper Industry. Springer Berlin Heidelberg; 1999:141-70.

6. Balakrishnan H, Dutta-Choudhary N, Srinivasan MC, Rele MV. World J Microbiol Biotechnol 1992;8:627.

7. Bansod SM, Dutta-Choudhary M, Srinivasan MC, Rele MV. Xylanase active at high $\mathrm{pH}$ from an alkalo tolerant Cephalosporium species. Biotechnology Letters 1993;15:965-70.

8. Bapat VA, Trivedi PK, Ghosh A, Sane VA, Ganapathi TR, Nath P. Ripening of fleshy fruit: molecular insight and the role of ethylene. Biotechnology Advances 2010;28:94-107.

9. Barekatain MR, Choct M, Antipatis C, Iji PA. Use Of Protease and Xylanase in Broiler Diets Contaning Distillers' Dried Grains with Solubles; $23^{\text {rd }}$ Annual Australian Poultry Science Symposium, Sydney, New South Wales; $19^{\text {th }}-22^{\text {nd }}$, February 2012.

10. Beg QK, Bhushan B, Kapoor M, Hoondal GS. Enhanced production of a thermostable xylanase from Streptomyces sp. QG-11-3 and its application in biobleaching of eucalyptus kraft pulp. Enzyme and microbial technology 2000;27:459-66.

11. Beg QK, Kapoor M, Mahajan L, Hoondal GS. Microbial xylanases and their Industrial applications: a review. App Microbio Biotechnoal 2001;56:326-38.

12. Belancic A, Scarpa J, Peirano A, Diaz R, Steiner J, Eyzayuirre J. Penicillium purpurogenum produces several xylanases: purification and properties of two of the enzymes. J Biotechnol 1995;41:71-9.

13. Biely P. Biotechnological potential and production of xylanolytic systems free of cellulases. In ACS Symp Ser 1991;460:408-16. 
14. Biely P, Kluepfel D, Morosoli R, Shareck F. Mode of action of three endo- $\beta-1,4$-xylanases of Streptomyces lividans; Biochimica et Biophysica Acta (BBA) - Protein Structure and Molecular Enzymology 1993;1162:246-54.

15. Borisjuk NV, Borisjuk LG, Logendra S, Petersen F, Gleba Y, Raskin I. Production of recombinant proteins in plant root exudates. Nature Biotechnology 1999;17:466-9.

16. Cesar T, Mrša V. Purification and properties of the xylanase produced by Thermomyces lanuginosus. Enzyme and Microbial Technology 1996;19:289-96.

17. Chaudhary P, Deobagkar DN. Characterization of cloned endoxylanase from Cellulomonas sp. NCIM 2353 expressed in Escherichia coli. Current Microbiology 1997;34:273-9.

18. Chen CC, Adolphson R, Dean JF, Eriksson KEL, Adams MW, Westpheling J. Release of lignin from kraft pulp by a hyperthermophilic xylanase from Thermatoga maritima. Enzyme and Microbial Technology 1997;20:39-45.

19. Chen HH, Li GQ. Effect of xylanase on pasting properties of flour and bread quality [J]. Science and Technology of Cereals, Oils and Foods 2010;1:5.

20. Chen YP, Hwang IE, Lin CJ, Wang HJ, Tseng CP. Enhancing the stability of xylanase from Cellulomonas fimi by cell-surface display on Escherichia coli. J Appl Microbiol 2012;112:45563.

21. Christakopoulos P, Kekos D, Macris BJ, Claeyssens $\mathrm{M}$, Bhat MK. Purification and characterisation of a major xylanase with cellulase and transferase activities from Fusarium oxysporum. Carbohydrate Research 1996;289:91-104.

22. Christov LP, Myburgh J, O'Neill FH, Van Tonder A, Prior BA. Modification of the Carbohydrate Composition of Sulfite Pulp by Purified and Characterized $\beta$-Xylanase and $\beta$-Xylosidase of Aureobasidium pullulans. Biotechnology Progress 1999;15:196-200.

23. Clark TA, McDonald AG, Senior DJ, Mayers PR. In: Biotechnology in Pulp and Paper Manufacture, Kirk TK, Chang HM, eds. Butterworth-Heinemann; 1990:153-67.

24. Davis CL, Donkin CJ, Hinch SA, Germishuizen P. The microbiology of pine bark composting: an electron-microscope and physiological study. Bioresource Technology 1992;40:195-204.

25. Dey D, Hinge J, Shendye A, Rao M. Purification and properties of extracellular endo-xylanases from alkalophilic thermophilic Bacillus Sp. Can J Microbiol 1992;38:436-42.

26. Elegir G, Sykes M, Jeffries TW. Differential and synergistic action of Streptomyces endoxylanases in prebleaching of kraft pulp. Enzyme Microb Technol 1995;17:954-9.

27. Fang TJ, Liao BC, Lee SC. Enhanced production of xylanase by Aspergillus carneus M34 in solid-state fermentation with agricultural waste using statistical approach. New Biotechnology 2010;27:25-32.
28. Fu J, Yang X, Yu C. Preliminary research on bamboo degumming with xylanase. Biocatalysis and Biotransformation 2008;26:450-4.

29. Ghosh M, Nanda G. Purification and some properties of a xylanase from Aspergillus sydowii MG49. Applied and Environmental Microbiology 1994;60:4620-3.

30. Giridhar PV, Chandra TS. Production of novel haloalkali-thermo-stable xylanase by a newly isolated moderately halophilic and alkali-tolerant Gracilibacillus sp. TSCPVG. Process Biochemistry 2010;45:1730-7.

31. Gupta N, Vohra RM, Hoondal GS. A thermostable extracellular xylanase from alkalophilic Bacillus sp. NG-27. Biotechnology Letters 1992;14:1045-6.

32. Gupta S, Bhushan B, Hoondal GS. Isolation, purification and characterization of xylanase from Staphylococcus sp. SG-13 and its application in bio bleaching of kraft pulp. Journal of Applied Microbiology 2000;88:325-34.

33. Haapala R, Linko S, Parkkinen E, Suominen P. Production of endo-1, 4- $\beta$-glucanase and xylanase by Trichoderma reesei immobilized on polyurethane foam. Biotechnology Techniques 1994;8:401-6.

34. Haltrich D, Sebesta B, Steiner W. Induction of xylanase and cellulase in Schizophyllum commune. In ACS Symposium Series 1995;618:305-18.

35. Hokanson CA, Cappuccilli G, Odineca T, Bozic M, Behnke CA, Mendez M, Crea R. Engineering highly thermostable xylanase variants using an enhanced combinatorial library method. Protein Engineering Design and Selection 2011;24:597-605.

36. Horikoshi K, Atsukawa Y. Xylanase Produced by Alkalophilic Bacillus No. C-59-2. Agricultural and Biological Chemistry 1973;37:2097-103.

37. Huichang C. Application of Xylanase in Fish Feed. Journal of Anhui Agricultural Sciences 2006;34.13:3077.

38. Iji PA, Barekatain MR. Implications for the Feed Industry, 2011. Available at cdn.intechweb.org.

39. Inagaki K, Nakahira K, Mukai K, Tamura T, Tanaka H. Gene cloning and characterization of an acidic xylanase from Acidobacterium capsulatum. Bioscience, biotechnology, and biochemistry 1998;62:1061-7.

40. Ito $\mathrm{K}$, Ikemasu $\mathrm{T}$, Ishikawa $\mathrm{T}$. Cloning and sequencing of Xyn A gene encoding xylanase A of Aspergillus kawachii. Biosci Biotechnol Biochem 1992;56:906-12.

41. Joshi, M. D., Hedberg, A., \& Mcintosh, L. P. (2008). Complete measurement of the pKa values of the carboxyl and imidazole groups in Bacillus circulans xylanase. Protein science, 6(12), 26672670.

42. Juodeikiene G, Basinskiene L, Vidmantiene D, Makaravicius T, Bartkiene E, Schols H; The use of $\beta$-xylanase for increasing the efficiency of biocatalytic conversion of crop residues to bioethanol;; Catalysis Today; Volume 167, Issue 1, 10 June 2011:113-21. 
43. Karaduman Y, Gokcan C, Onal L (2012); Effect of enzymatic pretreatment on the mechanical properties of jute fiber-reinforced polyester composites; Journal of Composite Materials, May 22, 20120021998312446826.

44. Khanna, S. (1993). Regulation, purification, and properties of xylanase from Cellulomonas fimi. Enzyme and microbial technology, 15(11), 990-995.

45. Khasin A, Alchanati I, Shoham Y (1993) Purification and characterization of a thermostable xylanase from Bacillus stearothermophilus T-6. Appl Environ Microbiol 59: 1725-1730.

46. Kim JH, Kim SC, Nam SW (2000). Constitutive overexpression of the endoxylanase gene in Bacillus subtilis. J. Microbiol. Biotechnol. 10: 551-553.

47. Kimura, I., Sasahara, H., \& Tajima, S. (1995). Purification and characterization of two xylanases and an arabinofuranosidase from Aspergillus sojae. Journal of fermentation and bioengineering, 80(4), 334-339.

48. Kumar, V., \& Satyanarayana, T. (2012). Thermoalkali-stable xylanase of a novel polyextremophilic Bacillus halodurans TSEV1 and its application in biobleaching. International Biodeterioration \& Biodegradation, 75, 138-145.

49. Lapidot, A., Mechaly, A., \& Shoham, Y. (1996). Overexpression and single-step purification of a thermostable xylanase from Bacillus stearothermophilus T-6. Journal of biotechnology, 51(3), 259-264.

50. Lee, S.F. and Forsberg, C.W. (1987) Purification \& characterization of and $\mathrm{L}$ drabinofenanosidase from clostridium acetabutylicum ATCC 824.

51. Lee RC, Hrmova M, Burton RA (2003). Bifunctional family 3 glycoside hydrolases from Barley with alpha-L-Arabinofuranosidase and betaD-Xyylosidase activity characterization, primary structure and $\mathrm{COOH}$-terminal processing. J. Biol. Chem. 278: 5377-5388.

52. Leelavathi, S., Gupta, N., Maiti, S., Ghosh, A., \& Siva Reddy, V. (2003). Overproduction of an alkaliand thermo-stable xylanase in tobacco chloroplasts and efficient recovery of the enzyme. Molecular Breeding, 11(1), 59-67.

53. Li, X. L., Zhang, Z. Q., Dean, J. F., Eriksson, K. E., \& Ljungdahl, L. G. (1993). Purification and characterization of a new xylanase (APX-II) from the fungus Aureobasidium pullulans Y-2311-1. Applied and environmental microbiology, 59(10), 3212-3218.

54. Li JY, Yang YL, Li CY, Liu WX. (2011). Optimization of Technology for High Extraction Rate of Juice from Strawberry by Enzyme Method. Acta Agriculturae Jiangxi, 9, 50.

55. Liu W, Zhu W, Lu Y, Kong J, Ma G. (1998). Production, partial purification and characterization of xylanase from Trichosporon cutaneum SL409. Process Biochemistry, 33(3), 331-336.

56. Magnuson, T. S., \& Crawford, D. L. (1997). Purification and characterization of an alkaline xylanase from Streptomyces viridosporus T7A. Enzyme and microbial technology, 21(3), 160-164.

57. Malagutti L, Colombini S, Rapetti L, Pirondini M, et al. Xylanase and benzoic acid in the fattening heavy pig: effects on growth performance and on nitrogen and energy balance. Energy and Protein Metabolism and Nutrition, 2010:403-4.

58. Mini-Encyclopedia of Papermaking Wet-End Chemistry. Available at http://www4.ncsu.edu/ hubbe/KRFT.

59. Momtazan R, Moravej H, Zaghari M, Taheri HR. A note on the effects of a combination of an enzyme complex and probiotic in the diet on performance of broiler chickens. Irish Journal of Agricultural and Food Research 2011;50:249-54.

60. Morales, P., Madarro, A., Flors, A., Sendra, J., \& Pérez-González, J. (1995). Purification and characterization of a xylanase and an arabinofuranosidase from Bacillus polymyxa. Enzyme and microbial technology, 17(5), 424-429.

61. Moreau, R. A., Powell, M. J., Whitaker, B. D., Bailey, B. A., \& Anderson, J. D. (1994). Xylanase treatment of plant cells induces glycosylation and fatty acylation of phytosterols. Physiologia Plantarum, 91(4), 575-580.

62. Morosoli, R., Roy, C., \& Yaguchi, M. (1986). Isolation and partial primary sequence of a xylanase from the yeast Cryptococcus albidus. Biochimica et Biophysica Acta (BBA)-Protein Structure and Molecular Enzymology, 870(3), 473-478.

63. Nakamura, S., Nakai, R., Wajabatacgu, K., Ishiguro, Y., Aono, R. and Horikoshi, K. (1994) Thermophilic alkaline xylanase from newly isolated alkaliphilic and thermophilic Baillus sp. strain TAR-I. Biosci. Biotechnol. biochem. 58, 78-81.

64. Nwodo-Chinedu S, Okochi VI, Smith HA, Omidiji 0 (2005) Isolation of cellulolytic microfungi involved in wood-waste decomposition: Prospect for enzymatic hydrolysis of cellulosic wastes. Int. J. Biomed. Health Sci. 1(2): 41-51.

65. Nwodo-Chinedu S, Okochi VI, Omidiji O, Omowaye OO, Adeniji BR, Olukoju D, Chidozie F (2007). Potentials of cellulosic wastes in media formulation. Afr J Biotechnol. 6(3): 243-246.

66. Okafor, U. A., Okochi, V. I., Onyegeme-Okerenta, B. M., \& Nwodo-Chinedu, S. (2010). Xylanase production by Aspergillus niger ANL 301 using agro-wastes. African Journal of Biotechnology, 6(14).

67. Østergaard, L. H., \& Olsen, H. S. (2010). Industrial applications of fungal enzymes. Industrial Applications, 269-290.

68. Paice, M., Bernier, M. and Jurasek L. (1988) Viscosity-enhancing bleaching of hardwood kraft pulp with xylanase from a cloned gene. Biotechnol Bioeng. 32:235-239.

69. Pal, A., \& Khanum, F. (2011). Efficacy of xylanase purified from Aspergillus niger DFR-5 alone and in combination with pectinase and cellulase to improve 
yield and clarity of pineapple juice. Journal of Food Science and Technology,48(5), 560-568.

70. Pappan, K. L., Corredor, D., Gerdes, B., Lee, D. A., Yelundur, S. A., Wu, X., \& Wang, D. (2009, May). Transgenic Expression of Endoglucanase and Xylanase Genes Increases Tobacco Digestibility and Biomass Conversion. In The 31st Symposium on Biotechnology for Fuels and Chemicals.

71. Patel, R.N., Grabski, A.C. and Jeffries, T.W. (1993) Chromophore release from fraff pulp by purified streptomyces sosciscleroticus lylamesnases. Appll. Microbiol. Biotechnol. 39:405-412.

72. Ratanakhanokchai, K., Kyu, K. L., \& Tanticharoen, M. (1999). Purification and properties of a xylanbinding endoxylanase from alkaliphilic Bacillus sp. strain K-1. Applied and environmental microbiology, 65(2), 694-697.

73. Ratto, M., Mathrani, I.M., Ahring, B. and Viikari, L. (1994) application of thermosfable lylavase of Dictyo glomus spices enzymatic treatment of kraft pulps. Appl. Microbiol, Biotechnol. 41, 130-133.

74. Ravanal, María-Cristina, Yeison Espinosa, Lorena Rosa, Inmaculada Vaca, Rubén Polanco, Jaime Eyzaguirre, Gloria Levicán, and Renato Chávez. "Glucose-induced production of a Penicillium purpurogenum xylanase by Aspergillus nidulans." Mycoscience 53, no. 2 (2012): 152-155.

75. Shao, W., DeBlois, S., \& Wiegel, J. (1995). A HighMolecular-Weight, Cell-Associated Xylanase Isolated from Exponentially Growing Thermoanaerobacterium sp. Strain JW/SL-YS485. Applied and environmental microbiology, 61(3), 937-940.

76. Sharma, P. K., \& Chand, D. (2012). Pseudomonas sp. xylanase for clarification of Mausambi and Orange fruit juice.

77. Silva RD, Yim DK, Park YK (1994) Application of thermostable xylanase from Humicola sp. for pulp improvement. J Ferment Bioeng 77: 109-111.

78. Simpson, B. K., Rui, X., \& XiuJie, J. (2012). Enzyme-assisted food processing.Green Technologies in Food Production and Processing, 327-361.

79. Stalin, T., Priya, B. S., \& Selvam, K. (2012). Ecofriendly application of cellulase and xylanase producing marine Streptomyces clavuligerus as enhancer in biogas production from waste. African Journal of Environmental Science and Technology, 6(6), 258-262.

80. Stutzenberger, F. J., \& Bodine, A. B. (2008). Xylanase production by Thermomonospora curvata. Journal of Applied Microbiology, 72(6), 504-511.

81. Suneetha V, Khan JA (2011); eds of chap 14 (p 259) in Soil enzymology (eds Shukla G, Verma A), Springer Verlag, 2011.

82. Tenkanen, M., Puls, J., \& Poutanen, K. (1992). Two major xylanases of Trichoderma reesei. Enzyme and microbial technology, 14(7), 566-574.

83. Tolan, J.S., Collins, J; Use of xylanase in the production of bleached, unrefined pulp at Marathon
Pulp Inc. Pulp \& Paper Canada 105(7): T167-169 (July, 2004).

84. Tremblay, L. and Archibald, F. (1993) Production of clowed Aylavase in Bacilluscerus and its performance in kraft prebleaching. Can. J. Microbiol. 39, 853-860.

85. Tsujibo, H., Miyamoto, K., Kuda, T., Minami, K., Sakamoto, T., Hasegawa, T., \& Inamori, Y. (1992). Purification, properties, and partial amino acid sequences of thermostable xylanases from Streptomyces thermoviolaceus OPC-520.Applied and environmental microbiology, 58(1), 371-375.

86. Uchino, F., \& Nakane, T. (1981). A Thermostable Xylanase from a Thermophilic Acidophilic Bacillus sp. Agricultural and Biological Chemistry, 45(5), 1121-1127.

87. Velkova, Z. I., Gocheva, V. K., Kostov, G., \& Atev, A. (2007). Optimization of nutritive media composition for hylanase production be aspergillus awamori. Bulgarian Journal of Agricultural Science, 13(6), 651.

88. Verhoeven T, Short F, Weightman R, Cowieson A, Isaksen MF; Xylanase inhibitors in UK wheat varieties: Survey of incidence and significance to pig and poultry feed; ADAS consulting, trimester report May, 2005 (no 56) for Home-Grown Cereals Authority (HGCA). Available at http://www.hgca.com/ publications/documents/cropresearch/RR56_Final_P roject_Review.pdf.

89. Verma, D., \& Satyanarayana, T. (2011). Cloning, expression and applicability of thermo-alkali-stable xylanase of Geobacillus thermoleovorans in generating xylooligosaccharides from agro-residues. Bioresource Technology.

90. Verma D, Satyanarayana T (2012) ; Molecular approaches for ameliorating microbial xylanases; Bioresource Technology Volume 117, August 2012, Pages 360-367.

91. Vicuna R, Escobar F, Osses M, Jara A (1997) Bleaching of eucalyptus kraft pulp with commercial xylanase. Biotechnol Lett 19: 575-578.

92. Viikari L, Ranva M, Kantelinen A, Sandquist J, Linko M (1986) Bleaching with enzymes. Third international conference in biotechnology in pulp and paper industry. 16-19 June, Stock holm, pp 6769.

93. Wilson, C. R., Tang, M. R., Christianson, T., Maurer, K. H., \& Weiss, A. (1999). U.S. Patent No. $5,888,800$. Washington, DC: U.S. Patent and Trademark Office.

94. Winterhalter, C., \& Liebl, W. (1995). Two Extremely Thermostable Xylanases of the Hyperthermophilic Bacterium Thermotoga maritima MSB8. Applied and environmental microbiology, 61(5), 1810-1815.

95. Woldesenbet, F., Gupta, N., \& Sharma, P. (2012). Statistical optimization of the production of a cellulase-free, thermo-alkali-stable, salt-and solventtolerant xylanase from Bacillus halodurans by solid 
state fermentation. Archives of Applied Science Research 2012:4:524-35.

96. Wong KKY, Saddler JN. (1992) Trichoderma xylanases: Their properties and application. In: Xylans and Xylanases (Visser, J., Beldman, G., Someren, M.A.K. and Voragen, A.G.J., Eds.), pp. 171-186, Elsevier, Amsterdam.

97. Yadav RD, Chaudhry S, Gupta S. Novel application of fungal Phanerochaete sp. and xylanase for reduction in pollution load of paper mill effluent. J Environ Biol 2012;33:223-6.

98. Yildirim YB, Turan F. Effect of Exogenous Enzyme Supplementation in Diets on Growth and Feed Utilization in African Catfish. Jounral of Animal and Veterinary Advances 2010;9:327-31.
99. Yoshioka H, Nagato N, Chavanich S, Nilubol N, Hayashida S. Purification and properties of thermostable xylanase from Talaromyces byssochlamydoides YH-50. Agricultural and biological chemistry 1981;45:2425.

100. Zhang SQHZJ, Xue-Zhi ZL. Effect of Xylanase Pretreatment of Wheat Straw Chemical Pulp Bleaching on Pollution Load of the Bleaching Effluent. Transactions of China Pulp and Paper 2008;1:8.

doi:10.5455/2319-2003.ijbcp20130602

Cite this article as: Goswami GK, Pathak RR.

Microbial xylanases and their biomedical applications:

a review. Int J Basic Clin Pharmacol 2013;2:237-46. 